УДК 613.2.032.33

Ю.М. МОТУЗКА

Київський національний торговельно-економічний університет

\title{
СПОЖИВЧА ОЦІКА АСОРТИМЕНТУ ТА ЯКОСТІ ПРОДУКТІВ ДЛЯ ЕНТЕРАЛЬНОГО ХАРЧУВАННЯ
}

Ю.Н. МОТУЗКА

Киевский национальный торгово-экономический университет

\section{ПОТРЕБИТЕЛЬСКАЯ ОЦЕНКА АССОРТИМЕНТА И КАЧЕСТВА ПРОДУТОВ ДЛЯ ЭНТЕРАЛЬНОГО ПИТАНИЯ}

I. MOTUZKA

Kyiv National University of Trade and Economics

\section{CONSUMER ASSESSMENT OF THE ASSORTMENT AND QUALITY OF ENTERAL NUTRITION FOODS}

\author{
https://doi.org/10.36910/6775-2310-5283-2019-12-03
}

Мета. Проведення споживчої оцінки асортименту та якості продуктів для ентерального харчування із застосуванням методології товарознавства для розроблення нових видів продуктів з урахуванням специфіки метаболізму хворих.

Методика. В основу методологічної бази дослідження покладено методи наукового пізнання, системного підходу та узагальнення. Для виявлення потреб та вимог споживачів до продуктів для ентерального харчування використовували результати попереднього опитування. Індекс задоволеності потреб споживачів визначали розрахунковим методом.

Результати. Розроблено модель вимог споживачів до продуктів для ентерального харчування. Модель базується на вимогах до їх функиіонального призначення, щцо визначається направленістю продуктів Ергономічні вимоги визначаються розширенням асортименту продуктів за рахунок використання різних товарних форм продуктів, сучасних видів паковання різної місткості, легкістю приготування, зручністю спожсивання продуктів; економічні - ціною, наявністю альтернативи існуючим продуктам для можсливості раціонального вибору за співвідношенням “иіна-якість"). Вимоги до інформативності є надбудовою моделі, які без базових вимог не створюють умов для ї ефективного функиіонування.

На основі даних щзодо рейтингу задоволеності та рейтингу важливості, розраховано індекс задоволеності потреб, за допомогою якого виявлено певні проблемні питання, які потребують вирімення задля максимізащії задоволення потреб споживачів. Встановлено, щуо нагальним нині є питання зниження вартості продуктів, щуо може бути досягнуто шляхом налагодження їх виробництва в Україні із використанням потенціалу вітчизняної сировинної бази; розширення асортименту продуктів із урахуванням специффічних потреб певних категорій споживачів та використання різних товарних форм $i$ паковальних матеріалів.

Наукова новизна. Запропоновано підходи до споживчої оиінки асортименту та якості продуктів для ентерального харчування із застосуванням методології 
товарознавства, які дали можливість визначити критерії їх споживних властивостей для розроблення нових видів продуктів з урахуванням специфіки метаболізму хворих.

Практична значимість. Одержані результати були використані при розробиі нових продуктів для ентерального харчування вітчизняного виробництва. Розроблені узагальнена модель вимог споживачів забезпечує виконання одного із базових принципів системи управління якістю - орієнтащію на споживача при формуванні асортименту продуктів для ентерального харчування.

Ключові слова: вимога, споживач, рейтинг, індекс задоволеності, потреба, продукт для ентерального харчування.

\section{Постановка проблеми у загальному вигляді та їі зв'язок з важливими} науковими та практичними завданнями. До продуктів для спеціальних медичних цілей, до яких належать продукти для ентерального харчування, апріорі висуваються підвищені вимоги щодо їх безпечності та якості $[1,2]$. Однак, враховуючи специфіку споживачів, їх фізичний та психологічний стан, що зумовлений видом ураження та/або певною хворобою значну роль відіграють органолептичні властивості продуктів, зручність їх споживання та зберігання, доступність та прийнятність з економічної точки зору.

Ефективність формування асортименту та якості продуктів для ентерального харчування залежить від своєчасного аналізування реального та потенційного попиту, оскільки ймовірність придбання продуктів залежить від сукупності чинників, серед яких суттєвими $є$ концепція продукту, корисність, безпечність і якість, смакові властивості, ціна, позиціювання на ринку, реклама та рекомендації медичних фахівців, відповідність очікуванням споживачів. Вибір продуктів для ентерального харчування залежить від багатьох чинників, зокрема стану хворого, специфіки захворювання, періоду лікувального етапу (до- та післяопераційний період, ранній реабілітаційний період в медичному закладі та віддалений в амбулаторних умовах) тощо [3]. Тому при розробці продуктів для ентерального харчування необхідним $\epsilon$ врахування вимог до них лікарів різного профілю, які безпосередньо використовують у своїй практичній діяльності продукти для ентерального харчування. Також доцільним для правильного позиціонування цієї групи продуктів вбачається визначення особливостей очікувань i вподобань цільового сегменту споживачів задля максимального задоволення їх потреб.

Аналіз останніх досліджень, у яких започатковано вирішення проблеми. Значний внесок у розробку наукових принципів формування критеріїв споживних властивостей продуктів для ентерального харчування, теоретико-практичних засад їх створення зробили вчені Хорошилов I.Є., Луфт B.M., Бєляєв A.B., Grasdalen P., Malone A, Wilkinson A.W., Wilmore D., 
Greenberg G.R та ін. Але просування на український ринок даної продукції та виробництво нових ії видів стримується недостатнім рівнем фундаментальних та прикладних досліджень з використання доступної вітчизняної сировинної бази У той же час вкрай необхідними є додаткові дослідження з визначення специфічних вимог до споживних властивостей продуктів, пов'язаних із особливими умовами їх споживання [1-5].

Цілі статті. Метою роботи $є$ проведення споживчої оцінки асортименту та якості продуктів для ентерального харчування із застосуванням методології товарознавства для розроблення нових видів продуктів 3 урахуванням специфіки метаболізму хворих.

Об'єкт дослідження. Об'єктом дослідження є система вимог до формування споживних властивостей продуктів для ентерального харчування.

Методи дослідження. В основу методологічної бази дослідження покладено методи наукового пізнання, системного підходу та узагальнення. Для виявлення потреб та вимог споживачів до продуктів для ентерального харчування використовували результати попереднього опитування. До анкетування були залучені науковці та практикуючі лікарі Української військово-медичної академії та іiї клінічних баз (НВМКЦ «Головний військовий клінічний госпіталь», Ірпінського військового госпіталю; Лікарні швидкої медичної допомоги) та пацієнти вищезазначених закладів. У опитуванні взяли участь 34 медичних працівники хірургічного профілю та 149 пацієнтів медичних закладів. Вибірка $є$ репрезентативною та має цільовий характер, похибка репрезентативності вибірки 3 імовірністю $0,945(\mathrm{P}=0,945)$ становила $3 \% \quad(\Delta=0,05)$. Отриману інформацію обробляли методом ранжування - розташуванням характеристик в порядку збільшення або зменшення їхньої важливості.

Індекс задоволеності потреб споживачів визначали розрахунковим методом. Наближення індексу задоволеності до одиниці свідчить про відповідність потреб і пропозицій та мінімальні відхилення, які, на думку споживача, існують між фактичними та бажаними показниками якості [6].

Виклад основного матеріалу дослідження з повним обгрунтуванням отриманих наукових результатів. До кола питань при анкетуванні лікарів були включені наступні: медична спеціалізація, досвід використання у практичній діяльності продуктів для ентерального харчування (підтверджена ефективність та проблеми), джерела надходження інформації про асортимент продуктів, переваги та недоліки представленої на ринку продукції, критерії вибору продуктів при їх призначенні пацієнтам, умови та спосіб використання 
продуктів, уподобання щодо паковальних матеріалів, товарної форми продуктів, зручності використання, та зберігання, вимоги до складу продуктів. Анкета для вивчення потреб та уподобань споживачів даної категорії продуктів містила такі питання: персональна інформація (вік, стать, рівень доходів), вид ураження, захворювання, джерела інформації про продукти, власний досвід щодо їх споживання, критерії вибору продуктів, уподобання щодо форми, органолептичних показників, паковання продуктів, зручності споживання та зберігання тощо.

На основі аналізу результатів анкетування розроблено узагальнену модель вимог споживачів до продуктів для ентерального харчування (рис. 1).

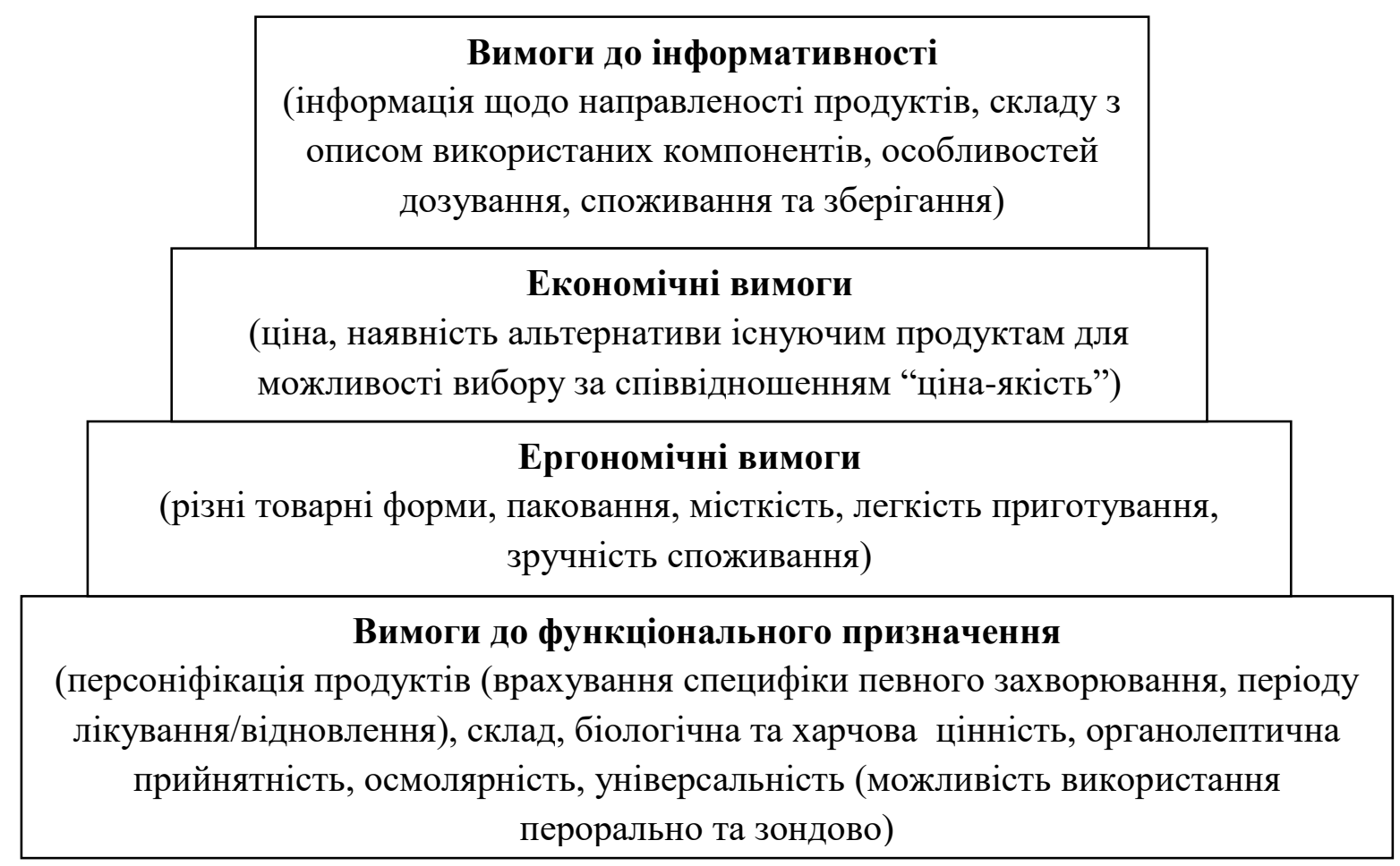

Рис. 1. Узагальнена модель вимог споживачів та лікарів до продуктів для ентерального харчування

Представлена модель базується на вимогах до їх функціонального призначення, що визначається направленістю продуктів (врахуванням специфіки певного захворювання, періоду лікування/відновлення), оптимізацією складу, біологічною та харчовою цінністю, прийнятними органолептичними показниками, осмолярністю, універсальністю використання (можливістю споживання перорально та зондово). Ергономічні вимоги визначаються розширенням асортименту продуктів за рахунок використання різних товарних форм продуктів, сучасних видів паковання 
різної місткості, легкістю приготування, зручністю споживання продуктів; економічні - ціною, наявністю альтернативи існуючим продуктам для можливості раціонального вибору за співвідношенням «ціна-якість»). Вимоги до інформативності є надбудовою моделі, які без базових вимог не створюють умов для їі ефективного функціонування. Використання узагальненої моделі направлено на забезпечення дотримання одного із семи принципів управління якістю - орієнтацію на споживача.

Використовуючи модель споживчих вимог та результати анкетування, визначено вимоги споживачів до показників якості продуктів для ентерального харчування та розраховано рейтинг споживачів щодо важливості показників та рейтинг їх задоволеності показниками якості (за 5-ти баловою шкалою) (табл. 1).

Таблиця 1

Рейтинг вимог споживачів до якості продуктів для ентерального харчування

\begin{tabular}{|c|c|c|c|}
\hline \multirow{2}{*}{$\begin{array}{l}\text { № } \\
3 / \Pi\end{array}$} & \multirow{2}{*}{ Показники } & \multicolumn{2}{|c|}{ Рейтинг } \\
\hline & & задоволеності & важливості \\
\hline 1. & $\begin{array}{l}\text { Наявність асортименту продуктів з урахуванням } \\
\text { специфіки певного ураження, захворювання }\end{array}$ & 2,44 & 4,12 \\
\hline 2. & Простота підготовки до споживання & 3,09 & 3,30 \\
\hline 3. & $\begin{array}{l}\text { Різноманітність товарних форм (суха суміш, } \\
\text { напій, драгль тощо) }\end{array}$ & 2,45 & 3,15 \\
\hline 4 & Повна та доступна інформація для споживачів & 3,60 & 3,87 \\
\hline 5. & Склад продукту & 3,29 & 4,02 \\
\hline 6. & Смак та запах & 3,10 & 3,55 \\
\hline 7. & $\begin{array}{l}\text { Пакування, що забезпечує } \\
\text { використання та зберігання }\end{array}$ & 2,88 & 3,89 \\
\hline 8. & Місткість паковання & 3,75 & 3,95 \\
\hline 9. & Термін зберігання & 4,52 & 2,84 \\
\hline 10. & Ціна & 2,30 & 4,95 \\
\hline 11. & $\begin{array}{l}\text { Універсальність } \quad \text { продукту } \quad \text { (можливість } \\
\text { перорального та зондового використання) }\end{array}$ & 3,72 & 4,14 \\
\hline
\end{tabular}

Аналіз даних таблиці свідчить, що найважливішими для споживачів є ціна, наявність асортиментної лінійки продуктів, що враховує специфіку певного ураження, захворювання, смак та запах, різноманітність товарних форм, наявність повної та доступної інформації. На основі даних щодо рейтингу задоволеності та рейтингу важливості, нами розраховано індекс задоволеності потреб (табл. 2), який сприяє виявленню тих показників, які 3 погляду споживача, $\epsilon$ найважливішими та потребують першочергового удосконалення $[7,8]$. 
Таблиця 2

Індекс задоволеності потреб споживачів

\begin{tabular}{|c|l|c|}
\hline $\begin{array}{c}\text { № } \\
3 / п\end{array}$ & \multicolumn{1}{|c|}{ Показники } & $\begin{array}{c}\text { Індекс } \\
\text { задоволе- } \\
\text { ності }\end{array}$ \\
\hline 1. & $\begin{array}{l}\text { Наявність асортименту продуктів 3 урахуванням специфіки } \\
\text { певного ураження, захворювання }\end{array}$ & 2,1 \\
\hline 2. & Простота підготовки до споживання & 1,4 \\
\hline 3. & Різноманітність товарних форм (суха суміш, напій, драгль тощо) & 1,5 \\
\hline 4. & Повна та доступна інформація для споживачів & 1,2 \\
\hline 5. & Склад продукту & 1,4 \\
\hline 6. & Смак та запах & 1,1 \\
\hline 7. & Пакування, що забезпечує зручність використання та зберігання & 1,3 \\
\hline 8. & Місткість паковання & 1,1 \\
\hline 9. & Термін зберігання & 1,2 \\
\hline 10. & Ціна & 2,2 \\
\hline 11. & $\begin{array}{l}\text { Універсальність продукту (можливість перорального та } \\
\text { зондового використання) }\end{array}$ & 1,1 \\
\hline
\end{tabular}

За результатами розрахунку індексу задоволеності виявлено певні проблемні питання, які потребують вирішення задля максимізації задоволення потреб споживачів. Встановлено, що нагальним нині $є$ питання зниження вартості продуктів, що може бути досягнуто шляхом налагодження їх виробництва в Україні із використанням потенціалу вітчизняної сировинної бази; розширення асортименту продуктів із урахуванням специфічних потреб певних категорій споживачів та використання різних товарних форм i паковальних матеріалів [9].

Таким чином, в результаті проведення досліджень щодо особливостей попиту серед медичних фахівців та безпосередніх споживачів (хворих, що перебувають на лікуванні у медичних закладах) визначено, що існуючий асортимент представлених на ринку України продуктів не задовольняє повною мірою вимог фахівців та очікувань споживачів, що підтверджує своєчасність та нагальність розробки продуктів вітчизняного виробництва.

Висновки та перспективи подальших досліджень. Розроблені узагальнена модель вимог споживачів забезпечує виконання одного із базових принципів системи управління якістю - орієнтацію на споживача при формуванні асортименту продуктів для ентерального харчування. Запропоновані підходи до оцінки потреб споживачів дали змогу виявити і 
сформулювати вимоги до продуктів для ентерального харчування та визначити критерії їх вибору. Одержані результати були використані при розробці нових продуктів для ентерального харчування вітчизняного виробництва.

\section{Список використаних джерел}

1. Хорошилов И. Е. Энтеральное питание: простое о сложном / И. Е. Хорошилов // Практическая диетология. - 2011. - № 3. - С. 36-40.

2. Луфт В. М. Клиническое питание в интенсивной медицине / В. М. Луфт, А. Л. Костюченко. - СПб. : Диля, 2002. - 174 с.

3. Беляев О.В. Парентеральное и энтеральное питание в интенсивной терапии / О. В. Беляев. - К. : КИМ, 2009. - 344 с.

4. Grasdalen P. The factors of enteral nutrition / P. Grasdalen // Crit. Care Med. - 2011. Vol. 6. - P. 142-157.

5. Malone A. Enteral formula selection: a review of selected product categories / A. Malone // Practical Gastroenterology. - 2005. - №28. - P. 44-74.

6. Белінська С.О. Управління безпечністю та якістю швидкозамороженої плодоовочевої продукції: дис. д-ра. техн. наук: 05.18.15/ Белінська Світлана Омелянівна. K., 2010. -472 c.

7. Алешина И.В. Поведение потребителей. - М.: ФАИР-ПРЕСС, 1999. - 384 с.

8. Ульвик Энтони. Чего хотят потребители / Ульвик Энтони ; [пер. с англ.] . - К.: Companion Group, 2007. - 224 c.

9. Притульська Н.В., Мотузка Ю.М. Товарознавчі засади позиціонування продуктів для ентерального харчування // Товари і ринки. - 2014. - №2. - С. 53-61.

Цель. Проведение потребительской оиенки ассортимента и качества продуктов для энтерального питания на основе методологии товароведения для разработки новых видов продуктов с учетом специфики метаболизма больных.

Методика. Для выявления потребностей и требований потребителей к продуктам для энтерального питания использовали результать предварительно проведенного опроса. Индекс удовлетворенности потребностей потребителей определяли расчетным методом.

Результаты. Разработана модель требований потребителей к продуктам для энтерального питания. Модель базируется на требованиях $к$ их фуннкционального назначения, которая определяется направленностью продуктов Эргономичные требования определяются расширением ассортимента продуктов за счет использования различных товарных форм продуктов, современных видов упаковки различной вместимости, легкостью приготовления, удобством потребления продуктов; экономические - ценой, наличием альтернативь существующим продуктам для возможности рачионального выбора по соотношению "цена-качество". На основе данных о рейтинге удовлетворенности и рейтинга важности, рассчитан индекс удовлетворенности потребностей, с помощью которого выявлены определенные проблемные вопросы, требующие решения для максимизачии удовлетворения потребностей потребителей. Установлено, что актуальным в настоящее время является вопрос снижения стоимости продуктов, что может быть достигнуто путем налаживания их производства в Украине с использованием потенциала отечественной сырьевой базы; расширение ассортимента продуктов с учетом специифических 
потребностей определенных категорий потребителей и использование различных товарных форм и упаковочных материалов.

Научная новизна. Предложены подходы к потребительской оценки ассортимента и качества продуктов для энтерального питания с использованием методологии товароведения, которые позволили определить критерии их потребительских свойств для разработки новых видов продуктов с учетом специффики метаболизма больных.

Практическая значимость. Полученные результаты были использованы при разработке новых продуктов для энтерального питания отечественного производства. Разработанные обобщенная модель требований потребителей обеспечивает выполнения одного из базовых принцииов системы управления качеством - ориентацию на потребителя при формировании ассортимента продуктов для энтерального питания.

Ключевые слова: требование, потребитель, рейтинг, индекс удовлетворенности, потребность, продукт для энтерального питания.

Purpose. To conduct consumer assessment of the assortment and quality of enteral nutrition foods using the methodology of commodity research, to develop new types of the foods with consideration to the specifics of the patients' metabolism.

Methodology. The research methodology is based on the methods of scientific cognition, system approach and generalization. Results of the previous interview are used to identify the needs and demands of consumers of enteral nutrition foods. The index of consumer needs satisfaction is derived by the calculation method.

Findings. A model for consumer requirements to enteral nutrition foods is developed. The model is based on their functional requirements to foods, determined by the purpose of foods. Ergonomic requirements are determined by the extension of the food assortment by use of various commodity forms of foods, advanced types of packaging with the varying capacity, easiness of cooking, convenience of food consumption; economic ones are determined by price, availability of alternatives to the existing foods, providing for rational choice by pricelquality ratio. Requirements to the informativeness are an add-on of the model, which cannot provide the conditions for its effective operation.

The ranks of satisfaction and the ranks of importance are used to calculate the index of consumer needs satisfaction, which is used to identify some problems calling for solutions in order to have the satisfaction of consumer needs maximized. It is found that a pressing issue of today is related with reduction of food price, which can be achieved by organizing their manufacturing in Ukraine and using the potential of the domestic resource base; by extending the assortment of foods with consideration to the needs of certain user categories and using various commodity forms and package materials.

Originality. The approaches to consumer assessment of the assortment and quality of enteral nutrition foods using the methodology of commodity research are proposed, which enable for defining the criteria of their consumer properties, to develop new types of foods with consideration to the specifics of the patients' metabolism

The practical value. The produced results were used in developing new enteral nutrition foods in Ukraine. The model generalizing the consumer requirements is capable to implement one of the principles underlying quality management: orientation on consumer when forming the assortment of enteral nutrition foods.

Keywords: requirement, rating, index of satisfaction, need, enteral nutrition foods.

Рекомендовано до публікації доктором технічних наук, професором КНТЕУ Белінською С.О. Стаття поступила в редакиію 12.02 .2019 р. 